\title{
O CONHECIMENTO SOBRE O PASSADO DOS BENS TOMBADOS QUE ABRIGAM MUSEUS: O SOLAR DO BARÃO DE JUNDIAÍ (JUNDIAÍ/SP) E A CASA DE PRUDENTE DE MORAES (PIRACICABA/SP)
}

The knowledge of the history of listed properties that house museums: Solar do Barão de Jundiaí (Jundiai/SP) and Casa de Prudente de Moraes (Piracicaba/SP)

LUCÍLIA SANTOS SIQUEIRA

http://dx.doi.org/10.1590/S0103-21862016000100010

Lucília Santos Siqueira é professora de História, Memória e Patrimônio do Curso de História da Unifesp (Isiqueira@ unifesp.br).

Artigo recebido em 29 de janeiro e aprovado para publicação em 1ํ de abril de 2016. 


\title{
RESUMO
}

Inserido numa pesquisa que analisa os bens tombados oriundos da sociedade cafeeira paulista (1830-1930), este artigo apresenta o Solar do Barão de Jundiaí, na cidade de Jundiaí/SP, e a Casa de Prudente de Moraes, localizada em Piracicaba/SP. Conhecendo o contexto de origem de cada uma dessas edificações, compreendendo sob quais razões se deram seus tombamentos, e como esses bens tombados se relacionaram com os museus históricos neles instalados, este texto pretende apreender a maneira como o bem tombado é apresentado para quem o visita. Assim, busca contribuir para o debate em torno da atualização dos significados desses bens edificados.

PALAVRAS-CHAVE: tombamentos; patrimônio cultural paulista; sociedade cafeeira.

\begin{abstract}
As part of a research that analyzes listed buildings from São Paulo coffee era (1830-1930), this article presents the Solar do Barão de Jundiaí, in the city of Jundiai/SP, and the Casa de Prudente de Moraes, in Piracicaba/ SP. By showing the context of origin of each of these buildings and understanding the reasons of their listing, and how they were related to the historical museums installed in them, this article intends to apprehend how a listed property is presented to its visitors. Thus, it seeks to contribute to the debate on the updating of the meanings attributed to these buildings.
\end{abstract}

KeYwords: heritage listing; São Paulo State cultural heritage; Brazilian coffee society.

\section{RÉSUMÉ}

Inséré dans une recherche qui analyse les immeubles classés comme patrimoine originaires de la société du café à São Paulo (1830-1930), cet article présente le Solar do Barão de Jundiaí, situé à Jundiaí/SP, et la Casa de Prudente de Moraes, à Piracicaba/SP. En partant de la connaissance du contexte d'origine de chacun de ces bâtiments, des raisons de leur classement et de comment a été leur relation avec les musées historiques qu'ils abritent, l'article cherche à saisir comment ces immeubles classés sont eux-mêmes présentés à ceux qui les visitent. Ainsi, nous cherchons à contribuer au débat sur la mise à jour des significations attribuées à ces immeubles.

Mots-CLÉs: classements; patrimoine culturel de São Paulo; societé du café au Brésil. 
elizmente, as políticas de patrimônio no Brasil têm incorporado o passado das po-

pulações indígenas e afro-descendentes, principalmente por meio da salvaguarda de bens imateriais. Entretanto, as centenas de bens materiais do passado brasileiro que foram tombados ao longo do século XX, em sua maioria remanescentes do universo cultural das elites, permanecem entre nós, obrigando-nos a conservá-los, em geral com recurso público.

Inserido numa pesquisa sobre os bens tombados oriundos da sociedade cafeeira paulista (1830-1930), este artigo apresenta duas edificações tombadas que abrigam museus históricos: o Solar do Barão de Jundiaí, na cidade de Jundiaí/SP, e a Casa de Prudente de Moraes, em Piracicaba/SP. Conhecendo o contexto de origem dessas edificações, compreendendo por que se deram seus tombamentos, e como elas se relacionaram com os museus históricos nelas instalados, pretende-se apreender como o bem tombado é apresentado para quem o visita. ${ }^{1}$ Assim, busca-se contribuir para o debate em torno da necessidade de rever e atualizar os significados atribuídos a esses bens edificados, visto que "a casa construída e habitada por uma das mais ilustres famílias paulistas", "a casa onde viveu e morreu o primeiro civil Presidente da República", "a casa onde se hospedou o Imperador" e outros atributos de tipo laudatório já não nos interessam.

Trata-se de subsidiar uma discussão em torno do sentido último desses tombamentos, isto é, para que devemos conservar essas edificações e, no limite, se devemos mesmo fazê-lo. 0 fato de o tombamento determinar a proteção permanente dos bens tombados, de não indicar um "prazo de validade" ou de renovação, facilita que não nos perguntemos, de quando em quando, por que manter protegida uma edificação; ao cabo, deixamos de atualizar seu significado e permanecemos investindo numa conservação cujo sentido escapa à sociedade e até aos especialistas.

Em princípio, imaginamos que abrigar um museu histórico qualifica uma edificação tombada. No entanto, como veremos, os museus de Jundiaí e de Piracicaba prescindem das casas onde estão instalados para tratar do passado.

Além das políticas oficiais de memória, nas últimas décadas mudou nossa maneira de nos relacionarmos com o passado, fazendo com que tenhamos novos interesses sobre ele (Gonçalves, 2015: 218). Precisamos discutir, então, o que gostaríamos de saber a partir de uma edificação que foi residência de gente poderosa no século XIX, quando se dava 0 
desenvolvimento da atividade cafeeira no Sudeste brasileiro. Neste texto não chegamos a tal proposição, mas buscamos balizar a discussão apresentando como e quais conteúdos e valores históricos se atribuíram a esses bens desde o seu tombamento e, por fim, apresentando 0 modo como essas edificações tombadas são mostradas na atualidade.

Como é próprio das reflexões do patrimônio cultural, tangenciamos ou adentramos temáticas variadas: a sociedade cafeeira paulista no Oitocentos, a história da arquitetura no território paulista, as vertentes da restauração, a rotina burocrática dos órgãos de patrimônio, as políticas de memória, a percepção e o manejo do passado, a história pública, a recepção cultural, as novas modalidades da expografia, a história dos museus, entre outras. Na medida em que o tratamento de nosso objeto solicita, o fôlego de nossa investigação permite e a dimensão desse texto acomoda, remetemos a autores especialistas.

\section{As EDIFICAÇÕES: CONTEXTOS DE ORIGEM, TOMBAMENTOS E CONSERVAÇÃO}

o centro da cidade de Jundiaí está o Solar do Barão de Jundiaí, tombado em 1970
pelo Conselho de Defesa do Patrimônio Histórico, Artístico, Arqueológico e Turístico do Estado de São Paulo - Condephaat (Condephaat, 1969a).

\section{Figura 1: A frente do Solar do Barão de Jundiaí, vista da Praça da Matriz.}

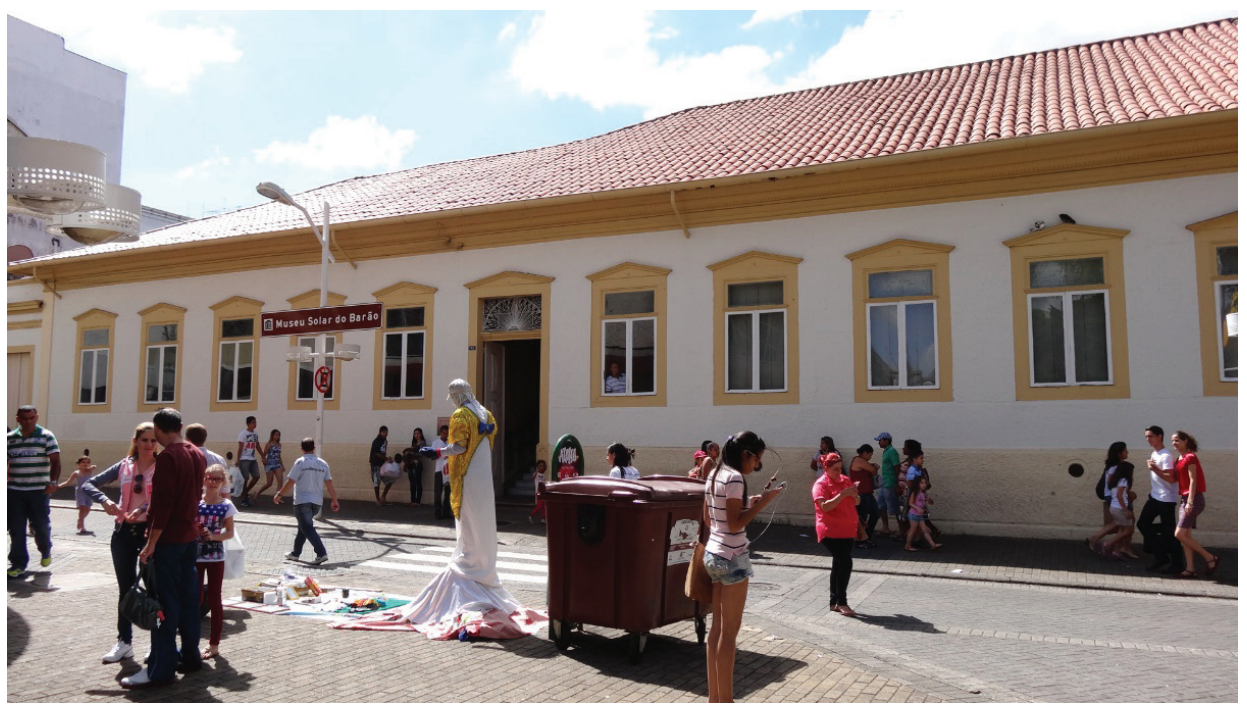

Fotografia tirada pela autora em 25 de abril de 2015. 
Pela bandeira de ferro da porta central, 1862 é a data inicial da casa; mas muitos afirmam que sua construção em taipa de pilão é do século anterior, e que a data na porta marca uma reforma realizada pelo proprietário, Antonio de Queiroz Telles (1789-1870), um grande fazendeiro da região, morador da zona rural, que mantinha a casa no núcleo urbano para as situações de negócio, festa e outros compromissos. Além de produtor de açúcar e café, Antonio de Queiroz Telles foi deputado provincial várias vezes desde 1835, hospedou o Imperador na casa em 1846, tornou-se Barão de Jundiaí em 1870 e constituiu uma descendência que manteve o uso residencial da edificação e o estatuto político e econômico da família Queiroz Telles.

Em 1969, quando o Condephaat mal começava a funcionar (Rodrigues, 2000), o conselheiro Vinício Stein Campos propôs o tombamento da "Casa do Barão de Jundiaí". Para o interesse aqui em tela - os conteúdos e valores históricos atribuídos aos bens -, o tombamento contou com dois pareceres, um histórico e um arquitetônico (Condephaat, 1969a: 6-8 e 10-13).

Para o historiador, o valor da edificação estava em ter sido propriedade da família Queiroz Telles e ter-se transformado em "palácio imperial" quando D. Pedro II nela se hospedou. Para os arquitetos, a casa era "por todos os títulos característica do ciclo econômico-social do café". Na ocasião da visita que fizeram a Jundiaí, em março de 1969, viram a casa somente por fora e afirmaram que estava fechada havia anos. Lembraram os arquitetos que as esquadrias e os vidros decorados estavam conservados e que nos fundos podiam ser vistos muros de taipa parcialmente demolidos. Recomendaram o tombamento, pois "não há em Jundiaí outra residência deste período que se lhe equipare como documento arquitetônico" . 0 relator sintetizou os pareceres dizendo que os arquitetos "elucidaram as vinculações históricas e arquitetônicas do imóvel aos antigos tempos paulistas" (Condephaat, 1969a: 21).

Em 1976, o imóvel passou da família Queiroz Telles para a Irmandade de São Vicente de Paulo, como está até hoje.

0 outro bem tombado aqui analisado é mais recente, erguido em tijolo nos anos finais da década de 1860 nas ruas centrais de Piracicaba. Depois da morte da mãe, em 1866, Prudente de Moraes (1841-1902) comprou o imóvel dos demais herdeiros, na Rua Santo Antonio; a casa ainda estava em construção. Advogado e casado, por volta de 1870 foi morar na casa com sua família. É evidente que a carreira política de Prudente de Moraes fez com que ele tivesse morado boa parte do tempo fora de Piracicaba. Ainda assim, o fato de ter morrido num dos quartos da casa revestiu-a de um valor maior, fazendo com que várias vezes, nos autos do patrimônio, ela seja denominada "a casa em que viveu e morreu o presidente Prudente de Moraes" (Siqueira, 2014). 
Figura 2: À direita, vista lateral da Casa de Prudente de Moraes.

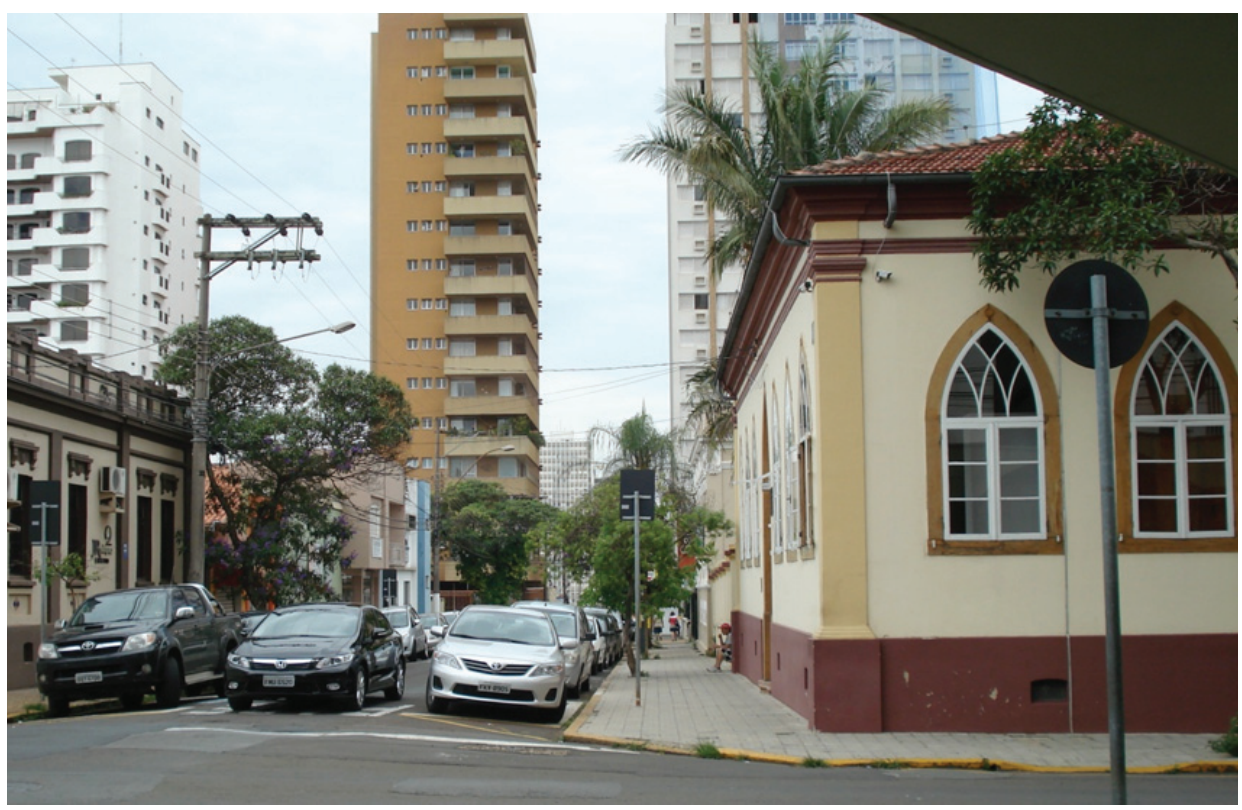

Fotografia tirada pela autora em 7 de dezembro de 2013.

A família Moraes Barros atuava do mesmo modo que os Queiroz Telles. Eram grandes fazendeiros e, entre seus membros, os bacharéis garantiam força política alcançando cargos importantes até no governo central.

No começo da década de 1930, quando foi vendida ao município, a Casa de Prudente de Moraes passou a abrigar instituições ligadas à educação. 0 Museu Histórico e Pedagógico Prudente de Moraes (MHPPM) instalou-se na casa em 1957 e, alguns anos depois, seu tombamento foi pedido ao órgão federal de patrimônio.

A Casa de Prudente de Moraes foi tombada nas três instâncias: na federal, o tombamento foi aprovado em 1969 e só foi efetivado em 2002; na estadual, em período coincidente com o tombamento do Solar do Barão de Jundiaí, o processo foi aberto em 1969 e encerrado em 1973; e no nível municipal, o pedido foi aceito no final de 2004. Uma boa análise desses três processos de tombamento está na dissertação de Maira Grigoleto (2009) e, também por isso, este artigo se ocupa de extrair desses autos o que diz respeito aos elementos históricos, principalmente no processo estadual, tramitado no Condephaat, a fim de estabelecer melhores relações entre os dois casos, o de Jundiaí e o de Piracicaba.

Como fez para o solar de Jundiaí, no começo de 1969 o conselheiro Stein Campos solicitou no Condephaat o tombamento da Casa de Prudente de Moraes. Chefe do Serviço 
de Museus Históricos, dizia ele que o tombamento se justificaria por ser "um indiscutível monumento histórico paulista" e "pela sua destinação [referia-se ao museu que lá estava desde 1957], evocativa da vida e da ação pública do imortal brasileiro"2 (Condephaat, 1969b: 2).

Desde o início dos estudos para o tombamento da Casa de Prudente de Moraes se explicitou que o valor histórico daquele bem era maior do que o arquitetônico. Em 1972, Carlos Lemos dizia que se tratava de um exemplar típico das casas térreas urbanas paulistas na segunda metade do Oitocentos: na frente, salas com grandes janelas nos dois lados; da frente até a varanda e a sala de jantar, um corredor central que começava com uns poucos degraus e era ladeado por alcovas e dormitórios; nos fundos, algumas frágeis edificações, "puxados", que abrigavam os serviços. Os arcos ogivais eram sinal da presença do imigrante europeu.

Para examinar os conteúdos históricos deste bem de Piracicaba na documentação do Condephaat que vai de 1969 a 2009, tratemos da relação entre a instância local e o Condephaat e do modo como a casa foi sendo compreendida pelos arquitetos ao longo do tempo (Siqueira, 2014).

Em 1976, três anos após o tombamento, o Museu Histórico e Pedagógico Prudente de Moraes (MHPPM) pediu ao Condephaat para restaurar o prédio (Condephaat, 1976b: 6). Encarregado da área de conservação, o arquiteto Carlos Lemos negou o pedido de restauro, respondendo que se tratava de obras de manutenção. Meses depois, o museu voltou com o pedido, desta feita justificando-o pela grandeza do que era veiculado pelo MHPPM, onde se apresentavam os "ilustres", aqueles que "enriqueceram a cultura nacional", como Prudente de Moraes, alguns barões da região e Luiz de Queiroz (Condephaat, 1976b: 10). Carlos Lemos respondeu que a casa estava ocupada por um "gabinete de curiosidades" e que se desrespeitava o seu caráter de "antiga residência"; aconselhava uma reformulação do museu para adequá-lo à casa, já que, diferentemente do que o museu solicitava, a área construída do terreno deveria ser diminuída, pois era preciso demolir os anexos erguidos na parte de trás para uso das escolas (Condephaat, 1976b: 13).

Vejamos o que pretendiam os projetos de restauro. Ao todo, foram três projetos nos quais o objetivo maior, várias vezes explicitado pelos arquitetos, era recuperar a configuração residencial primitiva do bem. Para tanto, chegou-se a dizer que a casa deveria ser entendida como "chácara", já que o terreno de trás abrigara árvores frutíferas e instalações para diversos serviços, o que levava a quererem mantê-lo como Lemos indicara já na década de 1970, livre das edificações que foram sendo construídas. 0 projeto mais recente, de 2006 , buscou recuperar a divisão interna original dos cômodos da residência da família Moraes Barros, destruindo as paredes erguidas para uso escolar na década de 1930; isso foi feito, entretanto, sem que 
se tivesse chegado a um entendimento sobre o uso "original" de cada cômodo (Condephaat, 1976b; Condephaat, 1983; Condephaat, 2006).

Em síntese, pode-se afirmar que tanto no Solar do Barão de Jundiaí como na Casa de Prudente de Moraes o tombamento e a conservação fizeram-se sob a égide de seus patronos, pois de começo se entendeu que o valor maior estava no fato de terem sido residência do barão de Jundiaí e do presidente Prudente de Moraes; ou, no mínimo, como disseram os arquitetos para Jundiaí, de serem "documento arquitetônico único" desse tipo de residência, ultrapassando a agência individual do barão e do presidente da República, mas mantendo a abordagem do bem como lugar de morada. Contudo, não se desenvolveu esse entendimento sob a perspectiva da recepção: como se mostra que o patrono viveu na casa? Quais aspectos desse habitar podem ser mostrados? A reflexão sobre a maneira de explicitar esses valores e conteúdos históricos para os cidadãos que visitam o bem tombado levaria os diferentes agentes a dialogar - os do órgão de patrimônio, os da prefeitura, os do restauro, os do museu, e ainda os proprietários, os movimentos sociais etc. (Castriota, 2011: 51).

Nos dois casos, o conteúdo histórico que circulou nos autos de tombamento e de conservação pouco se aprimorou ao longo do tempo. Alguns cacos de informação denotam que certas pessoas dispunham de conhecimento mais amplo sobre o assunto em pauta jornalistas, biógrafos locais, membros do Instituto Histórico, muitas vezes gente bem próxima do patrimônio -, mas esse conhecimento não se incorporou aos autos, assim como pareceres e projetos de restauro raramente foram acompanhados de bibliografia. A inclusão de bibliografia e o registro mais detalhado do conhecimento de certas pessoas permitiriam ampliar o escopo do que estava sendo tratado em termos históricos e consolidar a reflexão sobre o bem tombado.

No uso do passado para o manejo de um bem tombado, há diferenças entre os saberes de historiadores, arquitetos, museólogos e demais profissionais, sem falar nos diferentes grupos sociais que vêm ganhando participação nos processos de patrimonialização e de gestão de bens culturais. Além dessas diferenças, o exame da documentação revela permanente fragilidade no enunciar, no registrar e no fazer circular as informações sobre o passado. Ainda que não possamos cobrar dos que atuaram décadas atrás que tivessem o mesmo entendimento que temos hoje acerca de uma dada realidade passada, ainda assim apontamos que teria sido melhor estender o conteúdo histórico, compreender e registrar com mais miudeza e concretude o que vinha a ser, em cada momento, "antiga configuração residencial", " característico do ciclo econômico-social do café", "mantidos os elementos da construção original", "único exemplar arquitetônico". Cada uma dessas assertivas congregava diversas referências ao passado e expressava uma atribuição de valor assentada no passado; mas nenhuma delas se fazia 
tendo em mente como isso seria apreendido pelos cidadãos visitantes e, portanto, nenhuma delas apontava claramente o que isso queria dizer na fisicalidade do bem tombado. No nosso ponto de vista, expandir esses conteúdos sobre o passado por meio de estudo, explicitá-los mais detalhadamente nos registros dos autos - inclusive fotográficos -, faria com que os diferentes profissionais, ao longo do tempo, pudessem contar com um conjunto mais amplo de informações históricas para atuar junto ao bem patrimonializado, mesmo que se tratasse de um conjunto eivado de discrepâncias.

Ressaltemos, ainda, que a finalidade de consolidar um conjunto maior e melhor de informações sobre o passado nos autos do patrimônio não é fazer com que o significado atribuído no período do tombamento comande os trabalhos posteriores da conservação e tampouco que determine os usos da edificação; entendemos que a incorporação de mais conhecimento sobre o passado de um bem cultural colabora para sua desejável reinterpretação permanente (Gonçalves, 2012: 69-71).

\section{Os MUSEUS: INSTALAÇÃO E CONVIVÊNCIA COM AS EDIFICAÇÕES TOMBADAS}

E m 1972, dois anos depois do tombamento, a população de Jundiaí reclamava que 0 solar continuava fechado (Condephaat, 1969a: 60). Em maio de 1975, novamente se ouviram reclamos de Jundiaí, agora do prefeito, que escreveu pedindo a revogação do tombamento, pois a casa do barão permanecia abandonada e "enfeiando a praça principal da cidade" (Condephaat, 1969a: 105).

0 cerne do problema estava na indefinição das atribuições dos vários agentes. A Prefeitura e a Câmara Municipal teimavam em reverter a proteção, o Condephaat esperava por desapropriação e confirmava o tombamento, o Governo Estadual dizia não ter orçamento para desapropriar, as irmãs vicentinas diziam não ter recurso para as reformas e, ainda por cima, reclamavam que o tombamento as impedia de alugar o imóvel. 0 resultado era a velha edificação em deterioração crescente e a falta do museu prometido.

Todos entendiam que o melhor para o solar seria a desapropriação, pelo Estado ou pela Prefeitura; mas não havia recursos, e o encaminhamento foi um contrato de locação, em 1978, entre a congregação religiosa vicentina e a Prefeitura, pelo qual esta se comprometia a restaurar o solar no prazo de dois anos, sob a supervisão do Condephaat, "de modo a que o prédio fique em condições de ser utilizado como museu ou para qualquer outra finalidade cultural da Municipalidade de Jundiaí (...)" (Condephaat, 1969a: 181). 
O Museu Histórico e Cultural de Jundiaí foi criado em 1955, mas foi inaugurado em 1965, num outro prédio da cidade. ${ }^{3} 0$ museu só veio para o Solar do Barão quando terminaram as obras de restauro bancadas pela Prefeitura, em 1982 (Condephaat, 1976a: 163 e 164).

No caso de Jundiaí, o museu nunca se confundiu com a edificação tombada. Localizada em área de movimento, a casa ficou em arruinamento por mais de uma década, o que em si denunciava a ausência do museu e, obviamente, explicitava sua distinção em relação ao prédio. Hoje, na fachada do prédio a placa oficial anuncia com clareza a distinção: o Solar, "antiga residência do Barão de Jundiaí, tombado pelo Condephaat, abriga o Museu Histórico e Cultural".

Os autos de inúmeros bens paulistas armazenados no Condephaat e no IPHAN mostram um esforço vigoroso de construção da memória paulista a partir dos meados da década de 1950, no quadro que incluía as comemorações do IV Centenário da capital em 1954, a criação dos Museus Históricos e Pedagógicos de São Paulo em 1956 (Misan, 2008), a própria criação do Condephaat em 1968 (Rodrigues, 2000) e os trâmites para comemorar os 150 anos da Independência em 1972. Os dois museus aqui examinados nasceram nos meados da década de 1950, sendo o de Piracicaba ainda mais diretamente vinculado a este esforço de construção da memória paulista porque foi um dos quatro primeiros museus criados pelo Serviço de Museus Históricos até a década de 1970, quando a rede estadual chegou a 79 museus - os quatro para celebrar os presidentes da República "paulistas": Campos Salles em Campinas, Rodrigues Alves em Guaratinguetá, Washington Luís em Batatais e Prudente de Moraes em Piracicaba (Misan, 2008: 177)

Diferentemente da relação que o Museu Histórico e Cultural de Jundiaí estabeleceu ao longo do tempo com o Solar do Barão, o Museu Histórico e Pedagógico Prudente de Moraes sempre se confundiu com o bem tombado, sempre se sobrepôs à casa. Em Piracicaba, o museu instalou-se na edificação em 1957, sob a força dos planos do Serviço de Museus Históricos, uma década e meia antes de a casa ser tombada. Quando veio o tombamento, era como se este servisse para legitimar e laurear o museu. A predominância do MHPPM sobre a Casa de Prudente de Moraes aparece na confusão no uso de seus nomes, onde é frequente a referência ao bem tombado usando a denominação do museu, como na capa do processo de restauro de 2006, armazenado no Condephaat, onde se lê "Restauro do Museu Histórico e Pedagógico Prudente de Moraes".

Nesse sentido, foi a partir do museu que se pensaram os restauros para a Casa de Prudente de Moraes. Da década de 1970 até 2008 as demandas do MHPPM foram por aumentar a área edificada na parte posterior do terreno, o que contrariava a visão dos arquitetos do 
Condephaat. Embora os projetos de restauro afirmassem que pretendiam recuperar a configuração residencial do bem tombado, o resultado foi a construção das edificações necessárias para o museu, sem a recuperação da feição de "chácara". De todo modo, nunca se explicitou com exatidão o que se entendia por "chácara" e como isso se materializaria no terreno posterior da casa; nunca se esboçou um projeto para tal configuração.

Contudo, valem duas ressalvas. A primeira é a de que neste texto refletimos a partir dos bens tombados e não visamos diretamente os museus. Além disso, independentemente da avaliação sobre o resultado alcançado em Piracicaba, afirmamos que se chegou a ele sem um diálogo consistente acerca do que foi aquele espaço no passado e de como se poderia criar uma boa sede para o museu respeitando-o como a residência que foi. Se esse diálogo existiu, não ficou registrado nos autos.

Aos poucos foi prevalecendo a perspectiva de que o MHPPM era o responsável por tratar do passado da cidade e do presidente da República, e de que a casa valia para abrigar o museu e por seu valor evocativo. Segundo Simona Misan e Maira Grigoleto, a função desse museu era projetar a memória da atuação paulista no nascimento da República e mostrar a história da cidade, e isso sobrepôs-se ao valor atribuído ao bem tombado, que era o de ter sido residência de Prudente de Moraes (Misan, 2008; Grigoleto, 2009).

\section{COMO OS BENS TOMBADOS SE APRESENTAM AOS CIDADÃOS}

V

isitamos o Solar do Barão de Jundiaí no dia 25 de abril de $2015 .{ }^{5}$ Como sempre nesta pesquisa, para ver e refletir sobre os significados do bem cultural tombado "passamos" pelo museu, mas nosso foco não estava nas exposições museográficas.

Percorremos os recintos da casa tombada, por onde se distribuíam as exposições sobre diversos temas. Destas, extraímos aqui as que tratavam de aspectos históricos relacionados ao passado do bem tombado e do patrono. 0 maior recinto da casa, a grande sala da frente, à direita, mantinha os janelões fechados e abrigava a exposição sobre o barão e a família Queiroz Telles, com poucos e vistosos artefatos domésticos, como grandes tocheiros, majestosos espelhos de cristal, sofá e cadeiras de palhinha, telas a óleo retratando os membros mais ilustres da família e um ou outro painel que tratava de sua história. Havia ainda uma sala com mobiliário expográfico mais antigo, onde um painel de muita visibilidade apresentava a história de Jundiaí a partir das diferentes fachadas de sua igreja matriz; abaixo desse painel uma vitrine expunha objetos variados; no centro da sala, havia uma escarradeira sobre um pedestal. Vale mencionar, ainda, que em duas alcovas exibiam-se artefatos domésticos de uso mais íntimo - como camas, jarras de quarto, urinóis e oratórios. 
Figura 3: Sala da exposição sobre a família Queiroz Telles, onde se apresentam peças do mobiliário da casa.

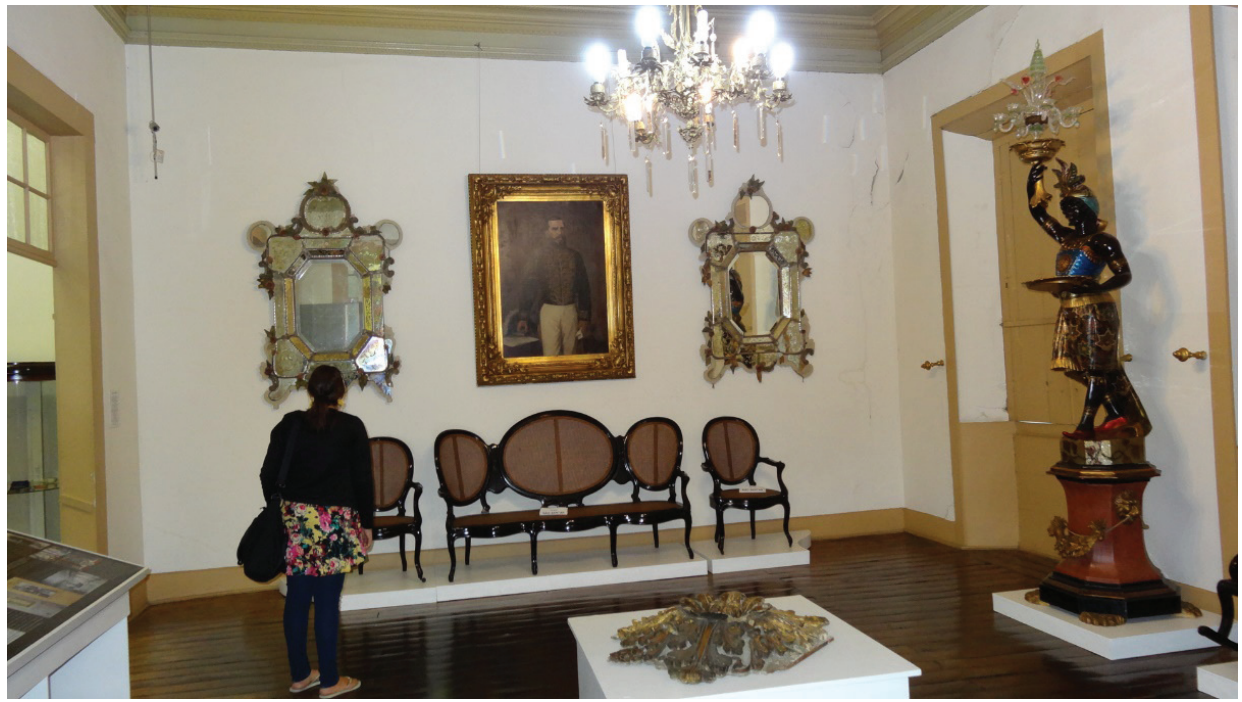

Fotografia tirada pela autora em 25 de abril de 2015.

Figura 4: Sala sobre a história de Jundiaí, onde se vê, à direita, o painel com as fachadas da matriz e a vitrine expondo objetos variados. À frente, o painel mostra as plantas da casa tombada.

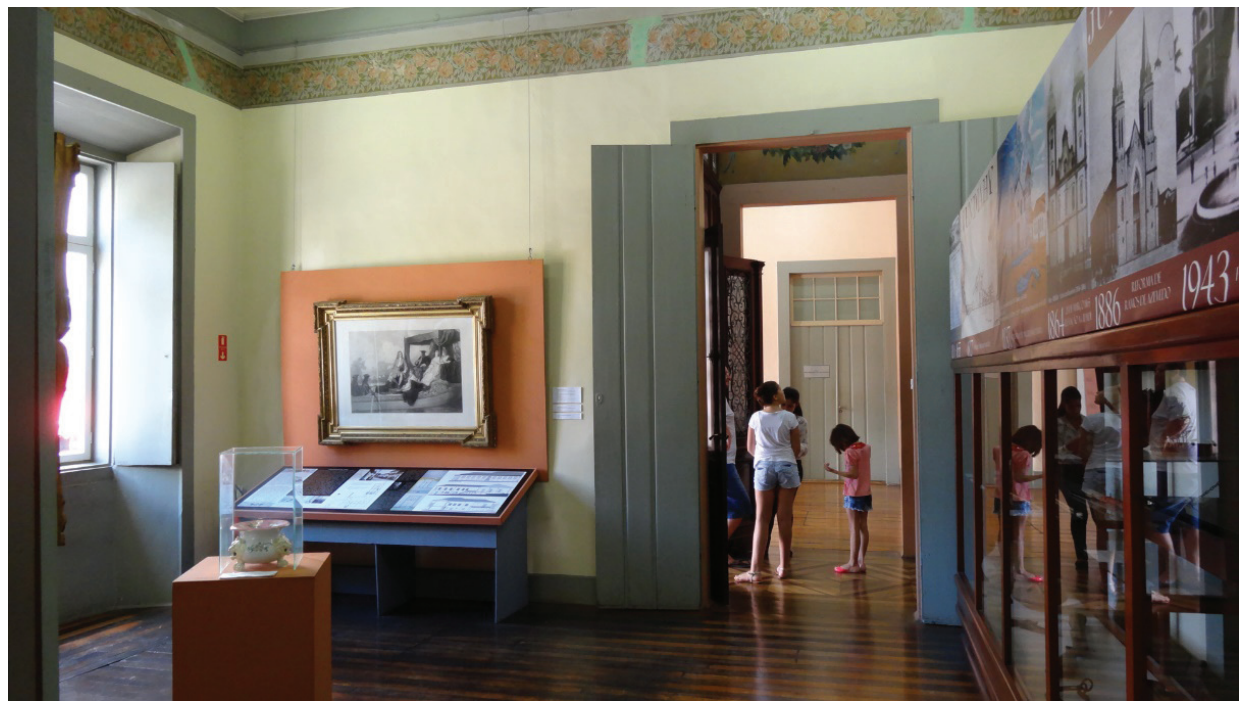

Fotografia tirada pela autora em 25 de abril de 2015. 
A partir da visita aos recintos da casa e também aos jardins da sua parte posterior, salientamos quatro aspectos para revelar como o bem tombado é apresentado ao cidadão.

Primeiramente, nas exposições do museu o bem cultural protegido Solar do Barão de Jundiaí está apresentado na sala referente à história de Jundiaí. Num painel, estabelecem-se as relações entre a cafeicultura, Jundiaí e a casa, tratando das construções em taipa; do lado direito desse mesmo painel apresentam-se desenhos da planta baixa e da fachada posterior da edificação, apontando que esta parte do solar teria sido reformada por Ramos de Azevedo no final dos anos de 1880. Noutro painel, numa tomada aérea, o solar é mostrado na sua implantação na quadra; há aí também uma dezena de fotografias menores de partes da casa antes da restauração do começo da década de 1980. Haveria muito que examinar nos elementos históricos apresentados pelo museu sobre o bem tombado, mas basta notar que a casa, como em tantos outros museus instalados em edificações "históricas", não é mostrada por seus elementos materiais ali presentes, visíveis e tangíveis, mas por meio da representação em painéis, em desenhos.

Em segundo lugar, apontemos duas pequenas excepcionalidades nas salas deste museu em que os painéis prevalecem. São dois papelinhos brancos afixados na parede da casa, na altura dos olhos. Um deles, medindo 5 centímetros de altura, explica em três linhas o que é uma alcova. 0 outro, uma folha inteira de sulfite, apresenta o "Solar do Barão" de modo claro

Figura 5: Na sala sobre a história de Jundiaí, o painel mostra fotografias da casa tombada e conta sua história.

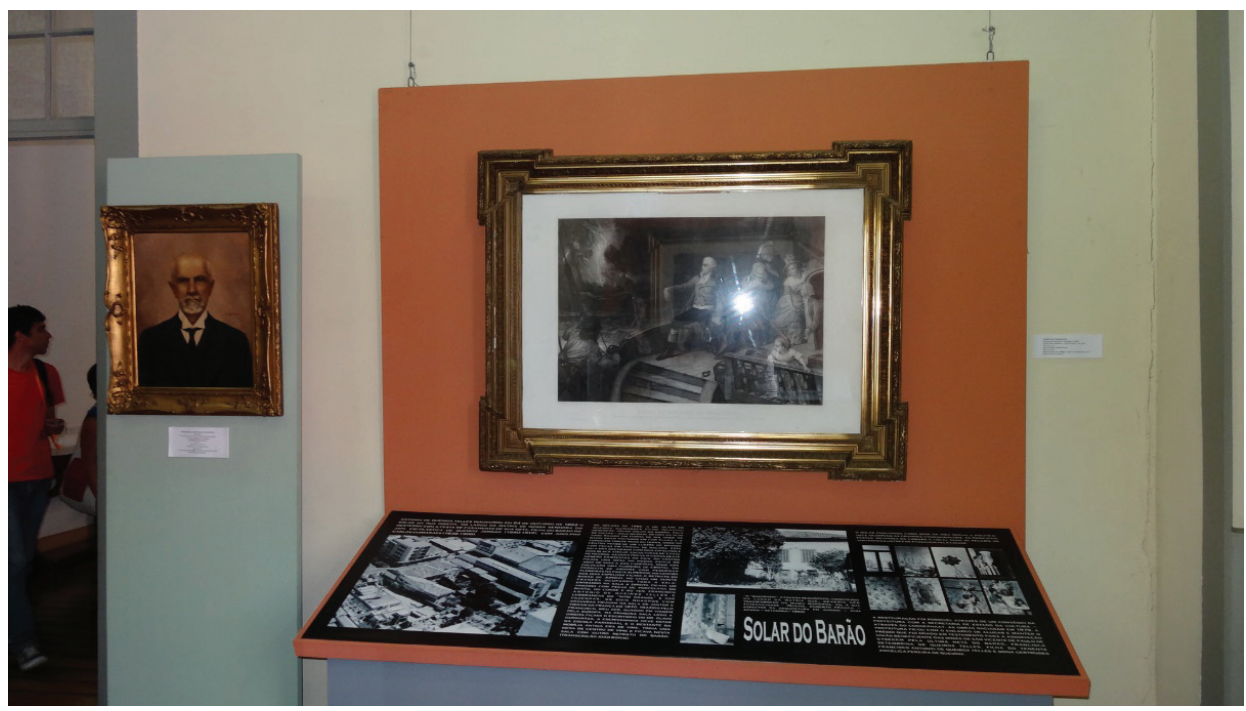

Fotografia tirada pela autora em 25 de abril de 2015. 
Figura 6: Na sala sobre a história de Jundiaí, o painel mostra fotografias da casa tombada e conta sua história.

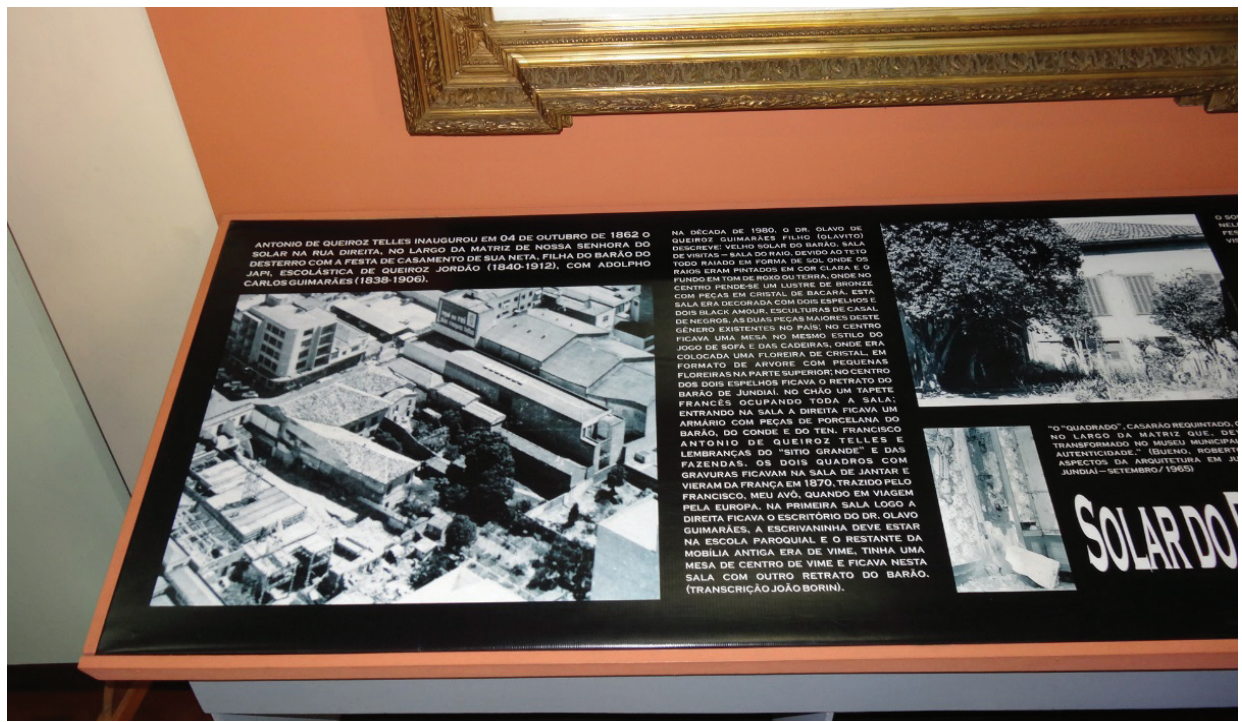

Fotografia tirada pela autora em 25 de abril de 2015.

Figura 7: Na sala sobre a história de Jundiaí, outro painel apresenta a planta baixa da casa e os desenhos de suas fachadas.

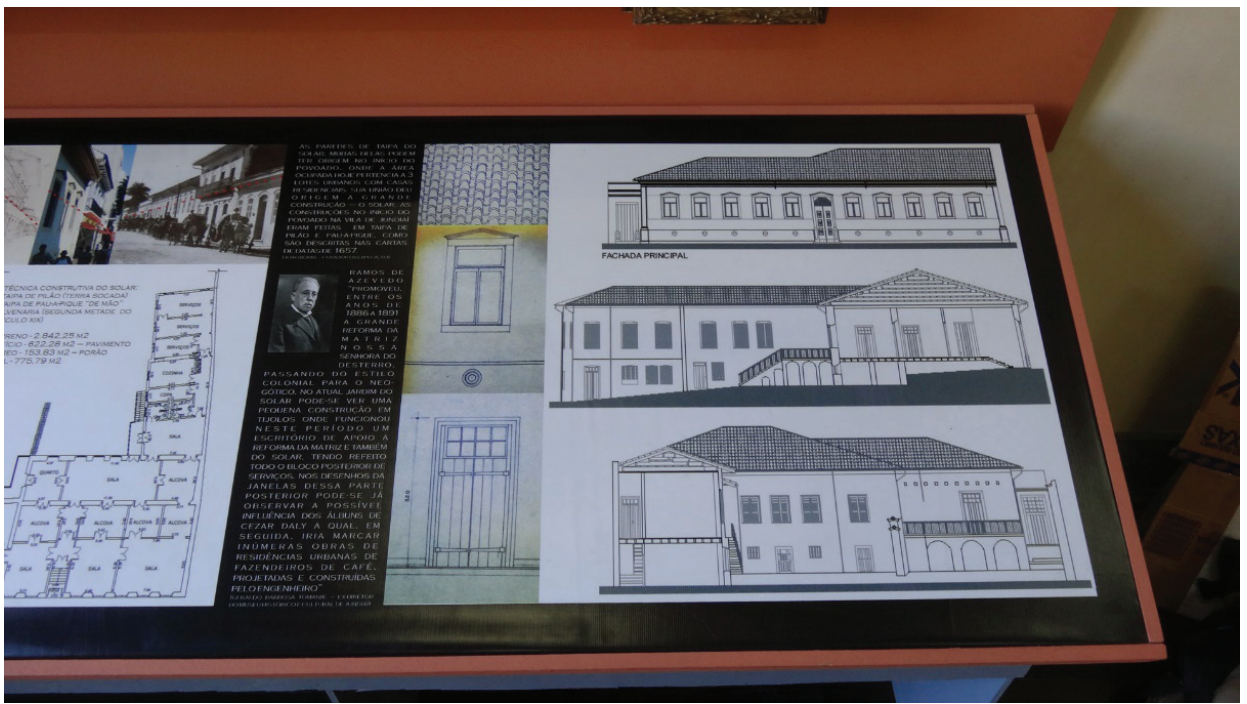

Fotografia tirada pela autora em 25 de abril de 2015. 
e sucinto, descrevendo-o arquitetonicamente - "na fachada principal, sequência de dez janelas e uma porta de entrada encimada com arco em ferro (...)" -, contando que pertenceu a Antonio de Queiroz Telles, que data de 1862, que foi construído em taipa de pilão rebocada, e que se trata de "construção urbana, com características de sede de fazenda do ciclo do café". Por fim, nas duas últimas linhas, destacado do restante, lê-se: "Solar - era assim chamado por ser uma casa nobre, de proporções avantajadas". Entendemos que, talvez por repetidas indagações dos visitantes, foi preciso afixar improvisadamente nas paredes informações primárias sobre a edificação, a residência, suas janelas, paredes, aqueles pequenos cômodos sem janela, como foi construída etc. É como se, embora algumas dessas informações estivessem nos painéis de forma mais elaborada, fosse necessário para o visitante acessar mais diretamente dados primários para compreender o que primeiro salta aos olhos: o prédio em que entrou, a casa de morada. Dado que as exposições, resultantes de pesquisa e reflexão, não facultam esse acesso direto, os singelos papéis tentam fazê-lo.

No final da visita, em conversa com o funcionário do museu, insinuaram-se os dois últimos pontos a tratar sobre o Solar do Barão de Jundiaí.

Desde a chegada ao solar fomos bem recebidos e acompanhados por um funcionário do museu com fala qualificada; de fato, tínhamos diante de nós um pesquisador, um

Figura 8: Na entrada para uma das alcovas, vêem-se os dois papéis brancos afixados, o pequeno à esquerda, no batente da porta, e o maior à direita, sobre a parede. Note-se a passagem em frente obstruída pelo mobiliário expográfico.

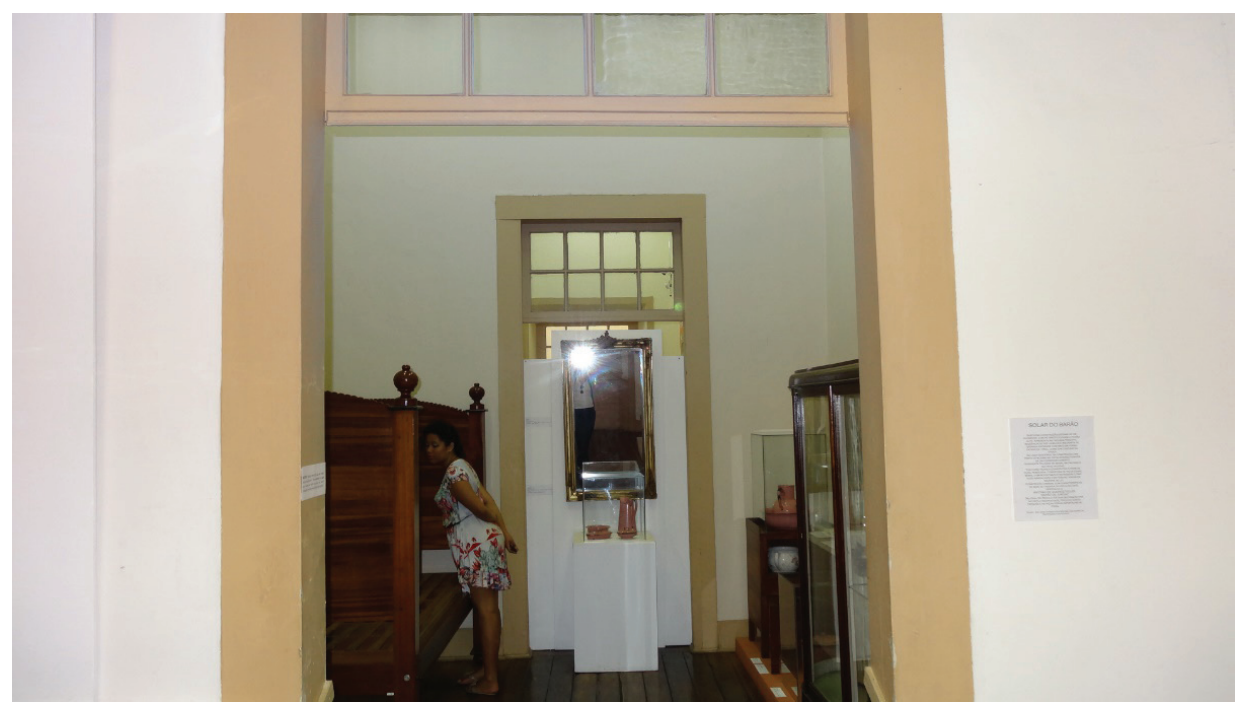

Fotografia tirada pela autora em 25 de abril de 2015. 
historiador que nos brindou com informações consistentes sobre a instituição e sobre a história da cidade. Ao responder sobre a casa, esclareceu sobre a propriedade do imóvel e as vicissitudes de uma instituição que funciona em edificação tombada, sobre a falta de recursos para a conservação etc. Entre as atividades do museu, contou-nos que outros profissionais preparavam um trabalho a ser desenvolvido nos jardins do solar, lidando com as plantas e seu cultivo, em torno de aspectos ambientais. Sem diminuir a urgência dos trabalhos de educação ambiental, vale marcar que esta única iniciativa do museu para manejar diretamente a materialidade do bem tombado, nos jardins, faz-se tendo em conta a natureza, e não a história, não o passado daquele local.

Figura 9: Parte posterior do bem tombado, onde se vê o portão que dá saída para os fundos da quadra.

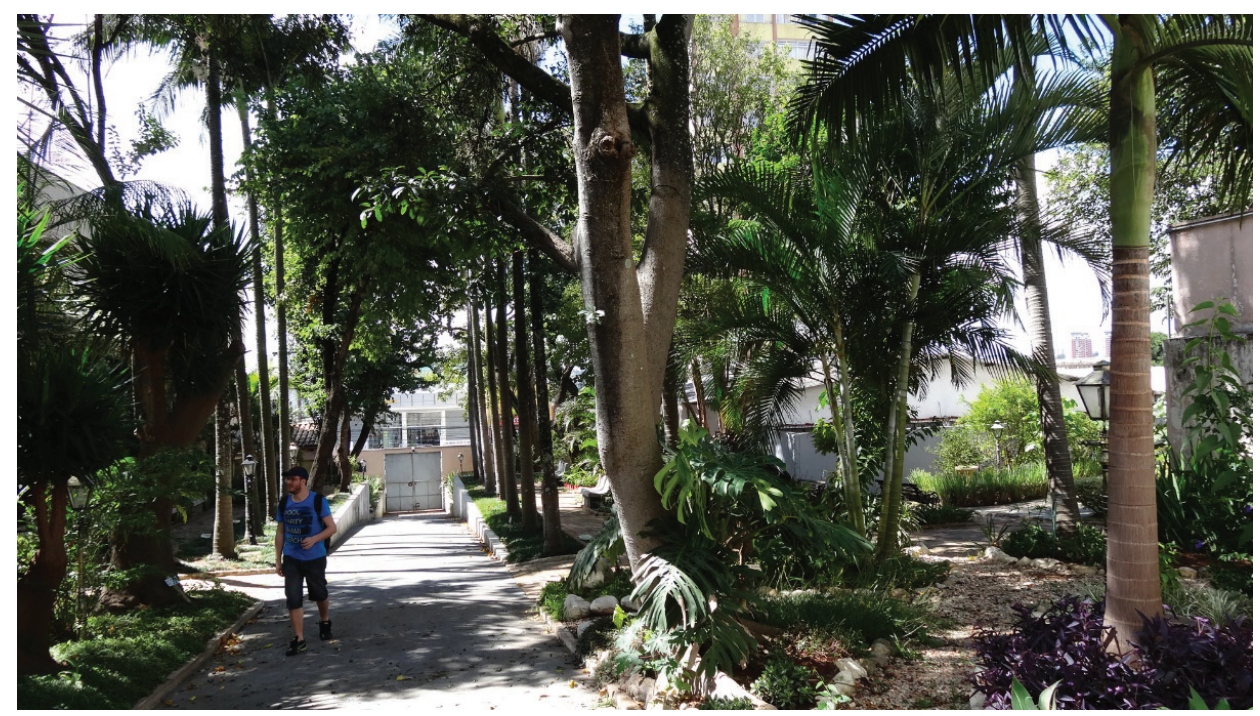

Fotografia tirada pela autora em 25 de abril de 2015.

O último ponto para refletir sobre como se apresenta o bem tombado também nos veio nesta conversa final. Ao tratar diretamente da relação entre o museu e a casa, o historiador afirmou: "costumamos dizer que a casa é do barão, mas o museu é nosso" - ou seja, o nosso lugar de interesse e de liberdade de ação é o museu. Com isso, quer-se dizer ainda que o fato de a casa ter pertencido a gente abastada faz com que não haja interesse por seu passado, talvez até um certo desprezo, e que, portanto, o passado que interessa só pode se mostrar por meio do museu, e não da casa. 
Em Piracicaba, a visita à Casa de Prudente de Moraes fez-se no final de 2013. Desde a entrada a impressão é a de estar num prédio público, que parece ter nascido sem qualquer traço de domesticidade. 0 corredor central, que, segundo Carlos Lemos, caracteriza as casas térreas urbanas paulistas do século XIX, está interrompido poucos metros depois da porta da rua pelo balcão de recepção do museu. Na parede ao lado encontra-se a placa oficial da reinauguração em 2009; nela se confundem os entes, museu e bem tombado: "Restauro e reestruturação do Museu Histórico e Pedagógico 'Prudente de Moraes'".

\section{Figura 10: Entrada da Casa de Prudente de Moraes, onde está a recepção do MHPPM. Notar a obstrução do corredor central da edificação.}

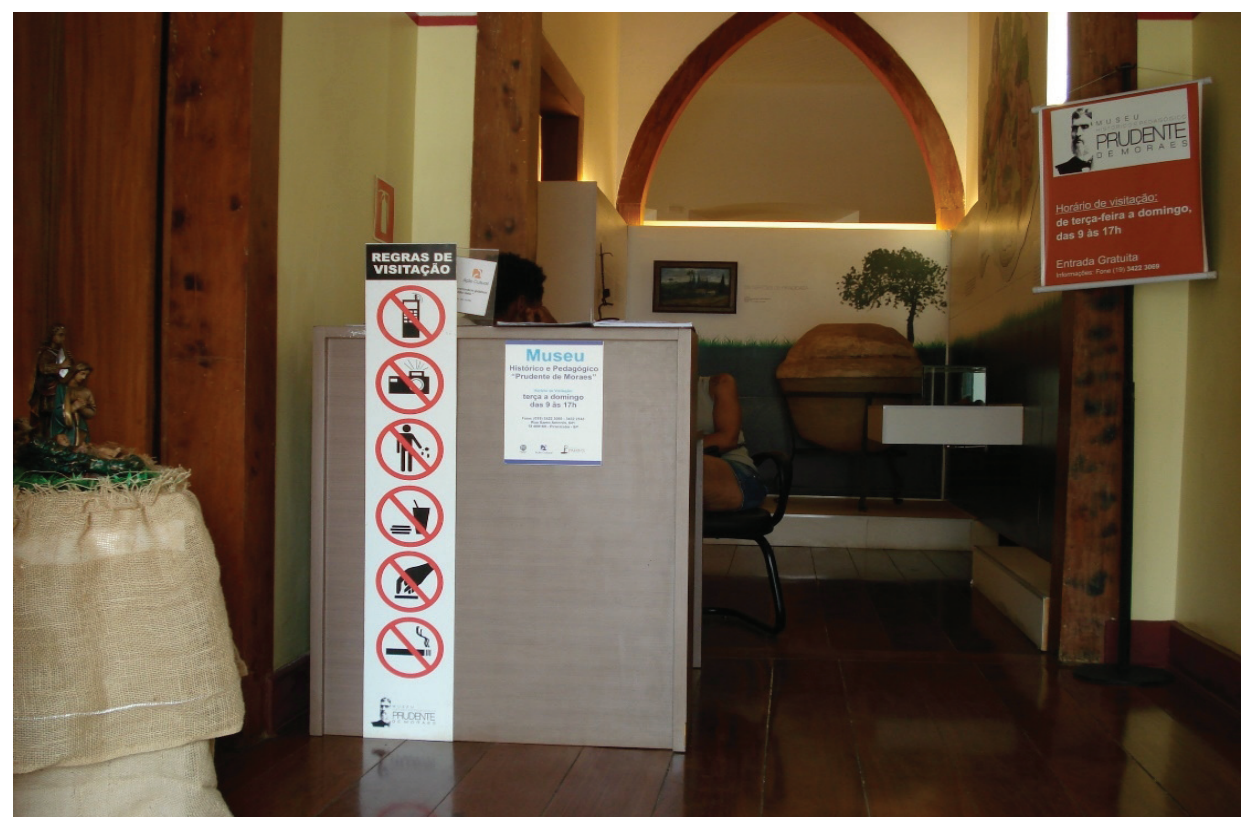

Fotografia tirada pela autora em 7 de dezembro de 2013.

À época desta visita, o MHPPM comportava duas exposições de média ou curta duração. Nas exposições de longa duração tratava-se da história do município; a partir da fundação de Piracicaba, narrava-se sua história até os meados do Novecentos. Se comparada à história municipal contada no museu de Jundiaí, a de Piracicaba mostra, sobremaneira na quantidade de informação, a atualização proporcionada pela reestruturação recente do museu piracicabano. ${ }^{6}$

A maior parte do museu está dedicada à trajetória política e particular de Prudente José de Moraes Barros. A exposição sobre o primeiro presidente civil do país está na sala 
mais ampla da edificação, que fica nos fundos, com as janelas dando para o quintal. Painéis fornidos de fotografias, objetos em vitrine e uma meia dúzia de telas de televisão veiculando fotografias e páginas de publicações antigas contam a história de Prudente de Moraes desde os tempos em que se tornou vereador até sua morte em 1902. Para uma ideia do caráter crítico e atualizado do museu, basta ver a sala escurecida que apresenta a atuação do presidente Prudente de Moraes diante da Guerra de Canudos, quando escreveu ao marechal Bittencourt dizendo estar ansioso pela notícia da morte do Conselheiro.

Embora a história do patrono esteja bem narrada, ao caminhar pelos recintos do museu o visitante não é chamado a ver os elementos da casa em que viveu o dito patrono. 0 único local em que Prudente de Moraes está diretamente relacionado com o prédio é o seu escritório de advogado, onde se pretendeu remontar o ambiente no qual ele teria trabalhado - curiosamente, o escritório não foi mencionado nos autos de tombamento e só aparece como objeto de intervenção bem tardiamente.

Figura 11: Mesa do escritório de Prudente de Moraes, onde o patrono atuou como advogado. Note-se a parede posterior do recinto inteiramente coberta por um painel do museu.

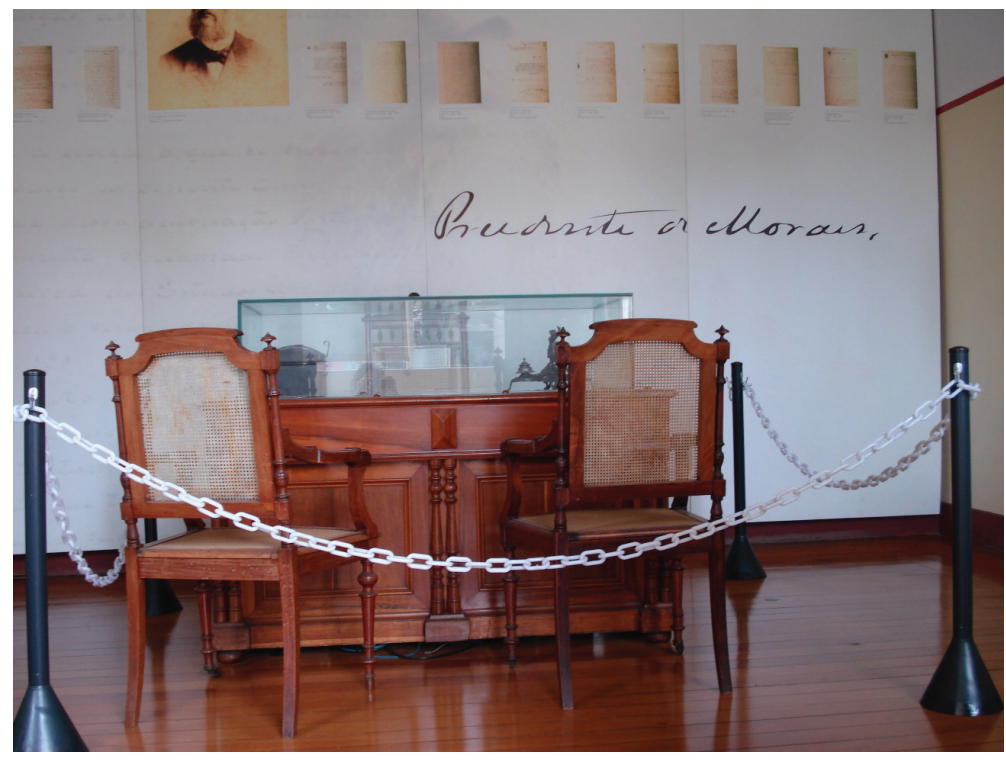

Fotografia tirada pela autora em 7 de dezembro de 2013.

Nas exposições, nada remete às paredes, divisões de cômodos, janelas, ornamentos ou qualquer outro elemento físico da edificação. Mais do que isso, nem mesmo no painel em que se narra o sofrimento da morte num dos quartos da casa, ou na altura em que se conta 
da casa ainda em construção comprada dos irmãos, em nenhuma circunstância há menção ao fato de que o prédio tratado nos painéis é aquele onde o visitante está.

Diferente do Solar do Barão de Jundiaí, esta casa tombada não se encontra representada imageticamente nas exposições de longa duração do museu, nem em desenho ilustrativo, nem em planta, tampouco em fotografia; talvez porque seu apelo estético seja ainda menor. Uma narrativa memorialística, exposta num painel atrás da casa, ao ar livre, retrata incidentalmente como era o quintal no tempo do presidente da República; sua ilustração remete aos acontecimentos narrados: o filho de Prudente de Moraes, o menino de sete anos que conta a história, diferentemente do que esperava, não foi castigado pelo pai por ter chupado jabuticabas no pé.

Figura 12: Na sala mais ampla da casa, a vitrine conta a trajetória de Prudente de Moraes. Notem-se as janelas fechadas e a iluminação artificial.

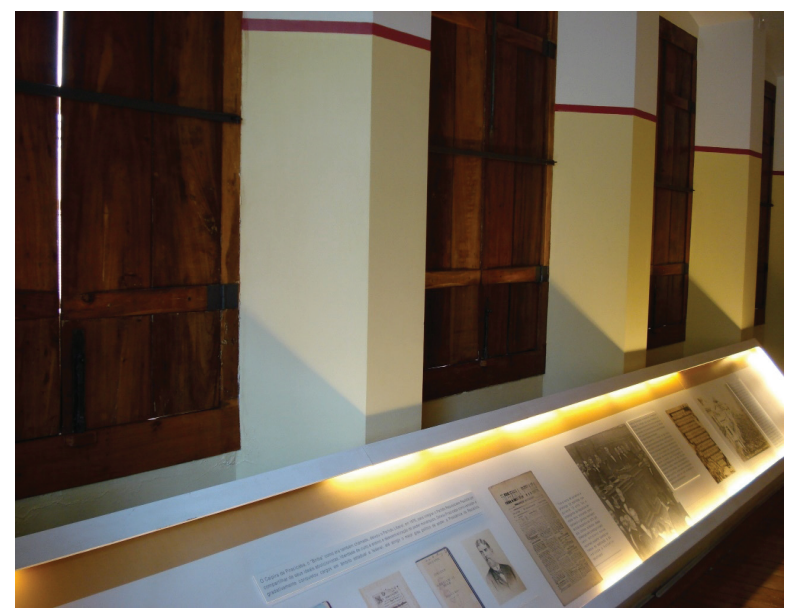

Fotografia tirada pela autora em 7 de dezembro de 2013.

Despojada dos elementos domésticos, como as benfeitorias do quintal, as árvores frutíferas, a cozinha e as instalações sanitárias, a casa ainda sofreu encobrimento pela maneira como 0 mobiliário expográfico foi disposto no seu interior - travando passagens, dificultando o acesso às janelas, obliterando as divisões entre os cômodos. Tudo isso, somado a uma iluminação artificial, à custa do fechamento das janelas e, portanto, do isolamento com relação aos jardins, ao quintal e à rua, criou uma ambiência em que a antiga casa do Oitocentos parece um estorvo.

Assim sendo, embora em relacionamentos diferentes com a edificação, tanto em Jundiaí como em Piracicaba, o museu promoveu o ocultamento da casa tombada. Mesmo que no primeiro caso a instalação do museu no prédio tenha sido posterior ao tombamento e em 
Figura 13: Na mesma sala da foto anterior, do lado oposto à vitrine, o mobiliário expográfico encobre as paredes e desconfigura a divisão interna da edificação.

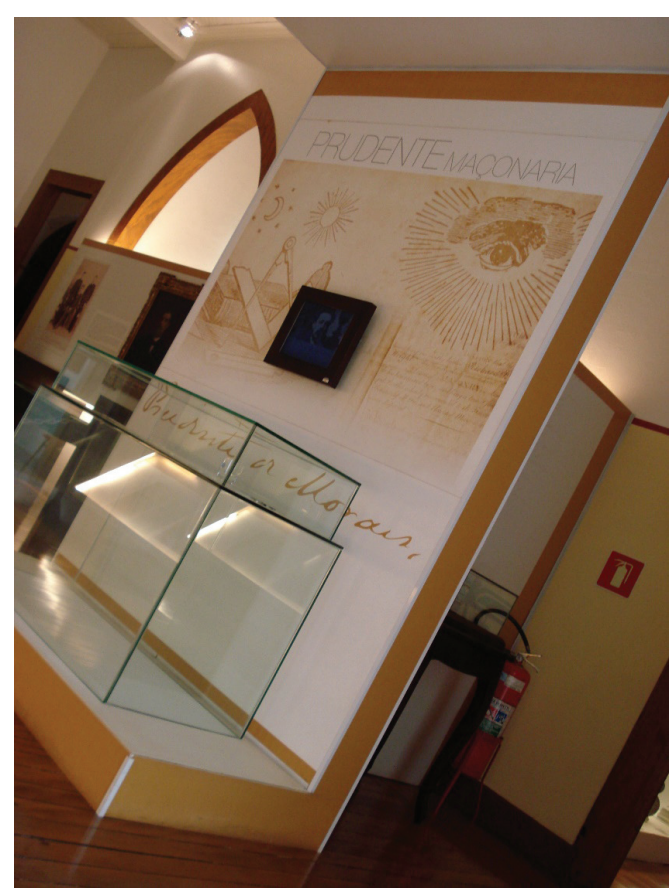

Fotografia tirada pela autora em 7 de dezembro de 2013.

Piracicaba o museu estivesse na casa mais de uma década antes de esta ter sido tombada, mesmo que os órgãos de patrimônio ao longo do tempo mantivessem o fato de os prédios terem sido residência do barão e do presidente da República como justificativa para a proteção, mesmo que as intervenções tenham buscado recuperar a morada original, ainda assim, as duas casas não são mostradas aos visitantes dos museus. Mantendo o foco nos bens tombados, é o caso de nos perguntarmos: seria necessário ou desejável que os museus estivessem nestes prédios? Se não estivessem, seria mais fácil apresentar as edificações tombadas? Se se entende que as casas tombadas e as instituições museais se enriquecem mutuamente, como isso pode se realizar para o visitante? ${ }^{7}$

\section{UM CONTRA-EXEMPLO E AS CONSIDERAÇÕES FINAIS}

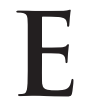
mbora tenham sido diferentes as relações entre os museus de Jundiaí e de Piracicaba e os prédios onde se encontram, cada uma dessas relações explica parte do ocultamento das casas que ocorre hoje. Para a compreensão do binômio museu/bem tombado, tem muita 
serventia saber quando e como o museu se instalou no local, quem o criou e para quê, se ali permaneceu ininterruptamente, se sofreu reestruturação recente etc. Não é apenas nas exposições e nas tarefas da gestão que um museu maneja a edificação onde se encontra. ${ }^{8}$

Tomemos um contra-exemplo, o caso de um museu que deixa ver o prédio velho de sua sede. 0 Palácio dos Azulejos, no centro da cidade de Campinas, bem tombado nos níveis federal, estadual e municipal, é ocupado desde 2004 pelo Museu da Imagem e do Som (MIS) (IPHAN, 1963; Condephaat, 1970; Condepacc, 1988).

Visitado em maio de 2014, o Palácio dos Azulejos foi construído em 1878 para morada de Joaquim Ferreira Penteado, que viria a ser o Barão de Itatiba. Na verdade, trata-se de duas residências, pois a esta primeira de 1878 juntou-se logo depois outra de mesma dimensão, para instalar a família de um dos filhos do barão. A denominação "palácio" decorreu de essas duas enormes casas terem sido ocupadas pela sede do Executivo municipal durante meio século (Lapa, 1996: 103-ss; Tonon, 2003).

Figura 14: Vista frontal do Palácio dos Azulejos na esquina da Rua Regente Feijó com a Ferreira Penteado. À esquerda, vê-se a emenda das duas residências.

A primeira, de 1878, é a da esquina.

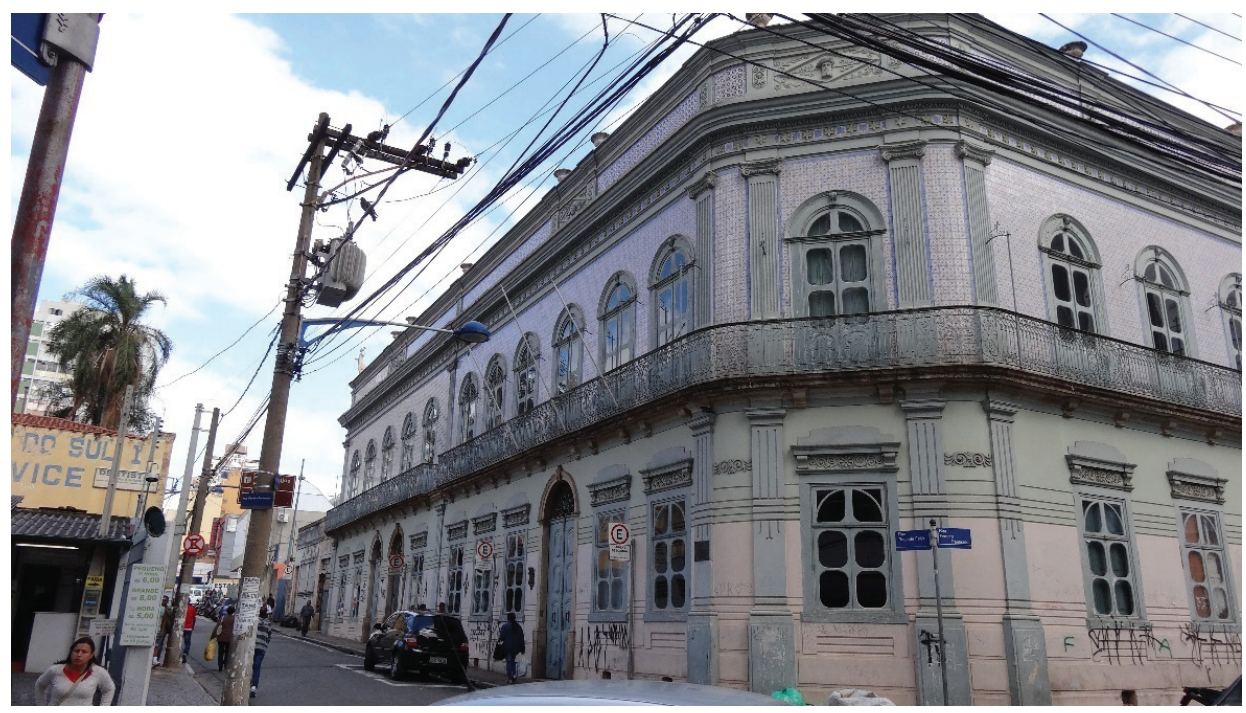

Fotografia tirada pela autora em 28 de maio de 2014.

Mesmo quando a prefeitura deixou o local, em 1968, outros órgãos da administração pública permaneceram no prédio quase até o final do século XX; entre eles, o órgão de patrimônio de Campinas, o Condepacc, o que seguramente contribuiu para apurar o tratamento dado à edificação tombada. 
O MIS, criado em 1975, só se instalou no Palácio dos Azulejos em 2004, após a edificação tombada passar por um restauro esperado e discutido havia muito tempo (Condephaat, 2000). 0 fato de essa restauração ter permanecido inacabada é decisivo para a boa visibilidade do bem tombado. Ao caminhar pelos recintos onde estão as exposições do MIS, saltam ao olhar do visitante as carnes de paredes expostas por falta de reboco e também as pinturas parietais parcialmente aparentes e em boa medida danificadas, criando um desconforto que força a ver a edificação, a notar sua ancianidade.

\section{Figura 15: Numa das salas do MIS, a restauração inacabada deixa ver parcialmente as pinturas parietais.}

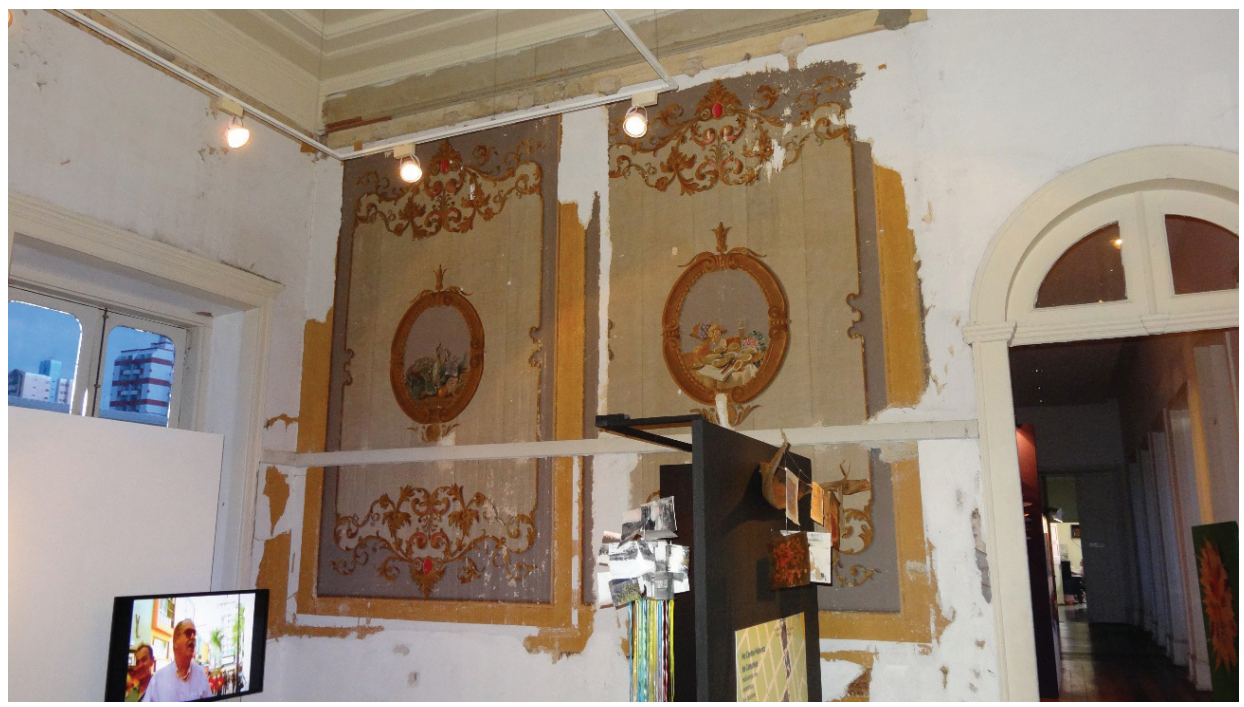

Fotografia tirada pela autora em 28 de maio de 2014.

O MIS, dedicado à imagem e ao som, diferentemente do Museu Histórico e Cultural de Jundiaí e do MHP Prudente de Moraes, não se propõe tratar da memória do barão que construiu sua sede. Poderíamos pensar que o museu permite ver o bem tombado porque este não coincide com seu objeto precípuo e, por isso, o MIS não apresenta um discurso sobre o palácio. Mas não é o que ocorre. Já no saguão de entrada há diversos painéis contando a história do bem tombado, desde sua origem residencial até a instalação do museu no local. Nesses painéis, na folheteria da recepção e na página do museu na internet, o MIS e o Palácio dos Azulejos são tratados como entes diferentes, mas que convivem: " o MIS com suas linguagens relacionadas à modernidade, $\mathrm{e}$ o Palácio, relacionado à tradição e ao poder, agora nesse novo uso, atualizado e democratizado", ou "a fusão do MIS com o Palácio dos Azulejos contribui para ampliar o potencial de memória de 
ambos no contexto cultural de Campinas" . 9 Mais do que as palavras afirmam, a homogeneidade da linguagem e da identidade visual para tratar do museu e do bem tombado, e o fato de elementos sobre o bem tombado e sobre o museu serem tratados conjuntamente, tudo isso mostra que se trabalhou em conjunto para que o museu estivesse funcionando no bem tombado, que os do museu se informaram sobre o prédio, que os profissionais do patrimônio não sabiam apenas sobre o bem tombado, mas também se inteiraram do que constituía o MIS e de como ele poderia "potencializar a memória" de Campinas. ${ }^{10}$

Retornando às casas objeto deste artigo, o fato de terem sido propriedade dos Queiroz Telles e dos Moraes Barros não impede que elas nos informem sobre aspectos da sociedade cafeeira paulista que ultrapassam as biografias do barão e do presidente da República. Elas tampouco precisam se reduzir a mostrar a riqueza eventual de sua vida doméstica (Ribeiro, 2012: 245). Essas casas do Oitocentos podem contar, por exemplo, como o mercado de consumo era estreito e muita coisa se produzia ou manufaturava no local de moradia, naqueles terrenos de trás da casa, onde se pilavam os grãos, limpavam-se as carnes, criavam-se animais, quarava-se a roupa, mantinham-se o pomar e as verduras. Também se pode contar como eram as situações de visita, onde se sentavam, de onde vinha o tal mobiliário, quais eram os comes e bebes e uma infinidade de coisas sobre a "face pública" da moradia. Pode-se cogitar a recuperação desses elementos do passado das casas oitocentistas e pode-se refletir sobre quais seriam as maneiras de apresentá-los aos visitantes; tudo isso pode-se fazer com ou sem a presença dos museus nessas casas.

A documentação armazenada nos órgãos de patrimônio e as visitas aos bens tombados têm mostrado que a incorporação de mais informações sobre o passado, em geral produzidas na universidade - mas não apenas neste ambiente -, poderia qualificar a maneira de apresentar os bens edificados (Bem, 2014; Motta, 2006). Como vimos acima, no entanto, às vezes a informação sobre o passado é consistente e crítica, mas se restringe ao exposto pelo museu, não alcança a edificação. Por isso entendemos que o impasse está em tomar a edificação na sua materialidade, como objeto do olhar.

Partilhando a visão de Ulpiano Bezerra de Meneses, de que o valor cultural é composto dos valores cognitivos, formais, afetivos, pragmáticos e éticos que existem em combinações variadas, às vezes conflituosas, pensamos que não é proveitoso distinguir os valores históricos dos arquitetônicos (Meneses, 2010: 35). Pode-se dar inteligibilidade ao passado por meio de informações sobre como se construiu uma edificação, a que formas estilísticas ela remete, por exemplo, ou sobre como diferentes pessoas habitaram, trabalharam ou visitaram aquele espaço doméstico. Antes mesmo das "informações", um bem tombado pode ser tomado sensorialmente, ou seja, o visitante pode ser convidado a percebê-lo pela forma, pelos atributos físicos que nos chegam pelos sentidos. 0 importante é que o histórico não seja relegado ao puramente 
evocativo, que não baste passar em frente ao bem tombado e saber que foi casa de fulano de tal. Se se trata de proteger, conservar e visitar a edificação, é desejável que ela seja objeto de conhecimento e de fruição, que possa qualificar nossa vida por meio de um entendimento do passado.

Felizmente, temos nos envergonhado de contar a história das elites da maneira como se fazia há algumas décadas. Já não faz sentido conhecer, por si só, a biografia ou a casa de um sujeito rico e poderoso que viveu há mais de um século. Como afirmamos no início, precisamos discutir o que interessa e o que se pode saber do passado a partir dessas casas oitocentistas tombadas; e precisamos fazê-lo tendo em mente como isso pode ser mostrado aos cidadãos que as visitam. Para isso, ajudaria bastante aprimorar a circulação dos conhecimentos históricos entre os agentes envolvidos nos processos de patrimonialização, de conservação e de musealização dos bens tombados.

\section{NotAs}

1 A intenção desta pesquisa é examinar a "apresentação" de bens tombados na atualidade, e não o modo como estes são recebidos pelos visitantes. Não se trata, portanto, de um estudo de "recepção cultural", onde seriam bem-vindos procedimentos de entrevista e/ou questionário junto aos visitantes. Trata-se aqui de um trabalho marcadamente historiográfico, que se ergue a partir do exame de fontes documentais armazenadas nos arquivos dos órgãos de patrimônio oficiais e dos conteúdos históricos veiculados nas exposições museográficas.

2 Os autos revelam que durante o processo estadual de tombamento da Casa de Prudente de Moraes as pessoas que estavam no Condephaat trabalharam sob a falsa ideia de que já se efetivara a proteção federal.

3 Disponível em http://cultura.jundiai.sp.gov.br/espacos-culturais/museu-historico-e-cultural-de-jundiai/ (acesso em 10 de janeiro de 2016).

4 Os últimos dados disponíveis no arquivo do Condephaat sobre restauração do Solar do Barão de Jundiaí encontram-se no Processo 21.985/82. Em 2005, o processo foi arquivado. Sobre a inauguração do museu: http://turismo.jundiai.sp.gov.br/atrativos/museus/museu-historico-e-cultural-de-jundiai-solar-do-barao/ (acesso em 10 de janeiro de 2016).

5 As visitas aos bens tombados do território paulista têm se realizado no âmbito do GVEPP - Grupo de Visitas, Estudo e Pesquisa em Patrimônio, que agrega estudantes do Curso de História da Unifesp e outros eventuais interessados no campo do patrimônio. Em todas as visitas nosso interesse é o bem tombado, o modo como é apresentado ao cidadão e a maneira como, por meio ou a partir da edificação, se apresentam os elementos do passado.

6 Em 2014 conversamos por telefone e por email com a diretora Renata Gava sobre esta reestruturação e outros aspectos da gestão do MHPPM. Na época, segundo ela, preparavam-se algumas atividades para lidar com os usos da moradia.

7 Uma investigação em torno dos órgãos de museus talvez mostrasse outros encaminhamentos para a relação com os prédios-sede e outros problemas para o pesquisador.

8 Para outra análise das relações entre os museus e os prédios onde se encontram, citemos aqui as apresentações de Maria Paula Vambiene e Regina Macedo Costa Dantas no I Encontro Luso-Brasileiro de Museus Casas, 
sobre o Museu Nacional e o Paço Nacional de São Cristóvão, localizado no Rio de Janeiro, onde residiram D. João VI, D. Pedro I e D. Pedro II (Vambiene, 2010; Dantas, 2010).

9 Disponível em http://miscampinas.com.br/sobre-mis.php (acesso em 22 de maio de 2014).

10 A existência de pesquisadores do campo do patrimônio na Universidade Estadual de Campinas - Unicamp criou na cidade um ambiente em que os debates sobre memória, políticas culturais, tombamentos e usos do espaço urbano são quase uma constante. Também por isso em Campinas há um órgão de patrimônio cultural funcionando no nível municipal desde os anos de 1980.

\section{REFERÊNCIAS BIBLIOGRÁFICAS}

BEM, Sueli de. Conversa de patrimônio em Jundiaí. São Paulo: EDUSP, 2014.

CASTRIOTA, Leonardo Barci. Conservação e valores: pressupostos teóricos das políticas para o patrimônio. In: GOMES, Marco Aurélio A. de Filgueiras e CORRÊA, Elyane Lins (orgs.). Reconceituações contemporâneas do patrimônio. Salvador: UFBA, 2011, p.49-66.

DANTAS, Regina Macedo Costa. A casa do imperador: uma reflexão sobre a relação entre D. Pedro II e o Museu Nacional Paço de São Cristóvão. In: Trabalhos apresentados no I Encontro Luso-Brasileiro de Museus Casas. Rio de Janeiro: Fundação Casa de Rui Barbosa, 2010, p.117-126.

GONÇALVES, José Reginaldo Santos. As transformações do patrimônio: da retórica da perda à reconstrução permanente. In: TAMASO, I. e LIMA FILHO, M. Antropologia e patrimônio cultural: trajetórias e conceitos. Brasília: ABA, 2012, p.59-73.

. 0 mal-estar no patrimônio: identidade, tempo e destruição. Estudos Históricos. Rio de Janeiro, v. 28, n. 55, p. 211-228, jan.-jun. 2015.

GRIGOLETO, Maira Cristina. A documentação patrimonial: gênese e fluxo dos processos de tombamento do Museu "Prudente de Moraes". Dissertação de mestrado. Programa de Pós-Graduação em Ciência da Informação. Faculdade de Filosofia e Ciências/Universidade Estadual Paulista (UNESP). Marília, 2009.

LAPA, José Roberto do Amaral. A cidade: os cantos e os antros: Campinas, 1850-1900. São Paulo: EDUSP, 1996.

MENESES, Ulpiano Bezerra de. 0 campo do patrimônio cultural: uma revisão de premissas. In: I Fórum Nacional de Patrimônio Cultural: Sistema Nacional de Patrimônio Cultural: desafios, estratégias e experiências para uma nova gestão, Ouro Preto/MG, 2009/ Instituto do Patrimônio Histórico e Artístico Nacional. Anais, v. 2, t. 1, p. 25-39. Brasília: IPHAN, 2010. Conferência Magna.

MISAN, Simona. Os museus históricos e pedagógicos do estado de São Paulo. Anais do Museu Paulista. São Paulo. Nova Série, v. 16, n. 2, p. 175-204, jul./dez.2008.

MOTTA, José Flávio. Escravos daqui, dali e de mais além: 0 tráfico interno de cativos em Constituição (Piracicaba), 1861-1880. Revista Brasileira de História, São Paulo, v. 26, n. 52, p. 15-47, 2006.

RIBEIRO, Marcus Tadeu Daniel. Entre o ser e o coletivo: 0 tombamento das casas históricas. Revista do Patrimônio Histórico e Artístico Nacional, Brasília, n. 34, p. 223-247, 2012.

RODRIGUES, Marly. Imagens do passado: a instituição do patrimônio em São Paulo: 1969-1987. São Paulo: UNESP/Imprensa Oficial do Estado/ Condephaat/Fapesp, 2000.

SIQUEIRA, Lucília Santos. A história da Casa de Prudente de Moraes em três tempos: no tombamento, nos restauros e na atualidade. Patrimônio e Memória, São Paulo, v. 10, n. 1, p. 48-67, jan./jun. 2014. 
TONON, Maria Joana. Palácio dos Azulejos: de residência a Paço Municipal (1878-1968). Dissertação de mestrado. Programa de Pós-Graduação em História. Instituto de Filosofia e Ciências Humanas/Universidade Estadual de Campinas (Unicamp). Campinas, 2003.

VAMBIENE, Maria Paula. A exposição histórica do Museu Nacional e do Paço Nacional de São Cristóvão: embate objeto e espaço. In: Trabalhos apresentados no I Encontro Luso-Brasileiro de Museus Casas. Rio de Janeiro: Fundação Casa de Rui Barbosa, 2010, p. 111-116.

\section{FONTES}

CONSELHO DE DEFESA DO PATRIMÔNIO HISTÓRICO, ARTíSTICO, ARQUEOLÓGICO E TURÍSTICO DO ESTADO DE SÃO PAULO. Solicita o tombamento do prédio conhecido por 'Casa do Barão de Jundiaí, em Jundiaí. 1969a: Processo 7857/69. São Paulo, 1969a.

CONSELHO DE DEFESA DO PATRIMÔNIO HISTÓRICO, ARTíSTICO, ARQUEOLÓGICO E TURÍSTICO DO ESTADO DE SÃO PAULO. Solicita o tombamento da Casa de Prudente de Moraes em Piracicaba. Processo 07861/69. São Paulo, 1969b.

CONSELHO DE DEFESA DO PATRIMÔNIO HISTÓRICO, ARTíSTICO, ARQUEOLÓGICO E TURÍSTICO DO ESTADO DE SÃO PAULO. Presidenta - Solicita autorização do Conselho objetivando firmar convênio com a Diretoria do Patrimônio Histórico e Artístico Nacional, evitando o destombamento do edifício conhecido como 'Palácio dos Azulejos', em Campinas. Processo 17270/70. São Paulo, 1970.

CONSELHO DE DEFESA DO PATRIMÔNIO HISTÓRICO, ARTíSTICO, ARQUEOLÓGICO E TURÍSTICO DO ESTADO DE SÃO PAULO. Restauração do Solar Barão de Jundiaí. Processo 20.171/76. São Paulo, 1976a.

CONSELHO DE DEFESA DO PATRIMÔNIO HISTÓRICO, ARTÍSTICO, ARQUEOLÓGICO E TURÍSTICO DO ESTADO DE SÃO PAULO. Restauração do imóvel onde funciona o Museu Histórico e Pedagógico Prudente de Moraes, em Piracicaba. Processo 20.041/76. São Paulo, 1976b.

CONSELHO DE DEFESA DO PATRIMÔNIO HISTÓRICO, ARTÍSTICO, ARQUEOLÓGICO E TURÍSTICO DO ESTADO DE SÃO PAULO. Obras de restauração (da $3^{a}$ etapa) do Solar Barão de Jundiaí. Processo 21.985/82. São Paulo, 1982. CONSELHO DE DEFESA DO PATRIMÔNIO HISTÓRICO, ARTíSTICO, ARQUEOLÓGICO E TURÍSTICO DO ESTADO DE SÃO PAULO. Solicita restauração do Museu Prudente de Moraes de Piracicaba. Processo 22.516/83. São Paulo, 1983.

CONSELHO DE DEFESA DO PATRIMÔNIO CULTURAL DE CAMPINAS. Tombamento ex officio do edifício situado à Rua Regente Feijó, do Barão de Itatiba - Palácio dos Azulejos. Processo 004. Campinas, 1988.

CONSELHO DE DEFESA DO PATRIMÔNIO HISTÓRICO, ARTíSTICO, ARQUEOLÓGICO E TURÍSTICO DO ESTADO DE SÃO PAULO. Encaminha projeto de restauração do Palácio dos Azulejos - Campinas. Processo 39829/00. São Paulo, 2000.

CONSELHO DE DEFESA DO PATRIMÔNIO HISTÓRICO, ARTÍSTICO, ARQUEOLÓGICO E TURÍSTICO DO ESTADO DE SÃO PAULO. Restauro do Museu Histórico e Pedagógico Prudente de Moraes. Processo 53621/06. São Paulo, 2006.

DIRETORIA DO PATRIMÔNIO HISTÓRICO E ARTíSTICO NACIONAL. Divisão de Estudos e Tombamento. Casa: (Museu Histórico e Pedagógico Prudente de Morais), Piracicaba. Processo 714-T-63. Rio de Janeiro, 1963.

DIRETORIA DO PATRIMÔNIO HISTÓRICO E ARTíSTICO NACIONAL. Divisão de Estudos e Tombamento. Palácio dos Azulejos, Campinas. Processo 0736-T-64. Rio de Janeiro, 1964. 